\title{
ULTRAVIOLET ELECTROLUMINESCENCE OF LED DEVICES BASED ON $n$-ZnO NANORODS GROWN BY VARIOUS METHODS AND $p$-GaN FILMS
}

\author{
B. I. Turko ${ }^{1, *(\mathbb{D})}$, A. S. Nikolenko ${ }^{2}$ D, B. S. Sadovyi ${ }^{3}$ (D) L. R. Toporovska ${ }^{1}$ (D), \\ M. S. Rudko ${ }^{1}$ (D), V. B. Kapustianyk ${ }^{1}$ (D), V. V. Strelchuk ${ }^{2}$ (D), R. Y. Serkiz ${ }^{1}$ (D) Y. O. Kulyk ${ }^{1}$ (D) \\ ${ }^{1}$ Ivan Franko National University of Lviv, \\ 50, Drahomanov St., Lviv, 79005, Ukraine \\ ${ }^{2}$ V. E. Lashkaryov Institute of Semiconductor Physics NAS of Ukraine \\ 41, Nauky Ave., Kyiv, 03028, Ukraine \\ ${ }^{3}$ Institute of High Pressure Physics PAS, \\ 29/37, Sokotowska St., 01-142, Warsaw, Poland
}

(Received 18 January 2020; in final form 17 September 2020; accepted 16 October 2020; published online 03 March 2021)

\begin{abstract}
Light emitting diodes (LEDs) structures based on $p$-GaN film $/ n-\mathrm{ZnO}$ nanorods quasiarray heterojunction were fabricated. $\mathrm{ZnO}$ nanostructures were grown on the $p$-type GaN templates using two different methods. The turn-on voltages of $\mathrm{ZnO} / \mathrm{GaN}$ heterojunctions based on $\mathrm{ZnO}$ nanorods grown using the gas-transport reaction and hydrothermal methods were equal to $3.2 \mathrm{~V}$ and $6.5 \mathrm{~V}$, respectively. The diode-ideality factors were estimated to be of around 45 and 36 for the samples with $\mathrm{ZnO}$ nanorods grown using the method of the gas-transport reaction and the hydrothermal method, respectively. The large values of the ideality factors can be explained by a high density of trap states and quality of the contacts with the $p-n$ junctions. The electroluminescence (EL) spectra of LEDs with $\mathrm{ZnO}$ nanorods grown by the gas-transport reaction and hydrothermal methods were approximated by four and three Gaussians, respectively. On the basis of the $X$-ray diffraction (XRD), electrical and optical studies data, one can conclude that the emission peaks at 389-391, 410-412, 436-438 and $502 \mathrm{~nm}$ correspond to the near-band-edge (NBE) recombination in $\mathrm{ZnO}$, interface carriers recombination in $\mathrm{ZnO} / \mathrm{GaN}$ junction, the electrons transition from GaN conduction band to $\mathrm{Mg}^{2+}$ doping level, and to the emission from the defect levels in $\mathrm{ZnO}$, respectively. The LED based on $\mathrm{ZnO}$ nanorods synthesized using the hydrothermal method emitted a more pure ultraviolet (UV) light.

Key words: zinc oxide, gallium nitride, nanorods, heterojunction, electroluminescence.
\end{abstract}

DOI: https://doi.org/10.30970/jps.25.1701

\section{INTRODUCTION}

Ga-containing materials still remain the main materials for the production of light emitting diodes and lasers with radiation at short wavelengths. The condition of further cheapening and increasing the energy efficiency of the optoelectronic devices demands application of cheaper wide band gap materials such as $\mathrm{ZnO}$ and "nonepitaxial" manufacturing technologies.

The most challenging problem of the electrooptic devices based on $\mathrm{ZnO}$ homojunction is the lack of stable and reliable $p$-type doping [1]. In this situation, $\mathrm{ZnO}$ based LEDs usually are fabricated by combining $n$-type $\mathrm{ZnO}$ with a $p$-type semiconductor other than $\mathrm{ZnO}$, for example, $\mathrm{Cu}_{2} \mathrm{O}$, ZnTe, $\mathrm{SrCu}_{2} \mathrm{O}_{2}, \mathrm{AlGaN}, \mathrm{GaN}$ or $p$-type conduction polymers [2, 3$]$.

The combination of $n$-type $\mathrm{ZnO}$ nanostructures and $p$-type GaN layers in a single heterostructure allows one to create the LED structure without using the expensive GaN material with $n$-type electrical conductivity, and at the same time to avoid the problems associated with a stable hole conductivity in $\mathrm{ZnO}$ and heterointerfaces quality [4].

In this paper, we compare the electroluminescent properties of the LEDs devices based on $n$ - $\mathrm{ZnO}$ nanorods grown using various methods on the $p$-type $\mathrm{GaN}$ templates.

\section{EXPERIMENT}

For the creation of the investigated heterojunction we used commercially available $p$-type GaN templates purchased from UNIPRESS (Poland) such as magnesium-doped GaN (0001)-oriented $2 \mu \mathrm{m}$ thick layer grown using the MOVPE method on a $430 \mu \mathrm{m}$ thick sapphire substrate with GaN non-conductive $1.5 \mu \mathrm{m}$ thick buffer layer. According to the passport data, $p$-GaN film is characterized by a relatively low dislocation density - (3-5) $\times 10^{8} \mathrm{~cm}^{-2}$; the concentration of the embedded magnesium impurity is $2 \times 10^{19} \mathrm{~cm}^{-3}$; the concentration of the electrically active holes is $(2-3) \times$ $10^{17} \mathrm{~cm}^{-3}$.

$\mathrm{ZnO}$ nanostructures were grown on the $p$-type GaN templates using two different methods. Figure 1 shows the $\mathrm{ZnO}$ nanorods produced using the method of gastransport reactions [3]. For seed-supported growth of $\mathrm{ZnO}$ nanorods, nanocrystalline $\mathrm{ZnO}$ seed particles were prepared in a solution of $0.005 \mathrm{~mol} / \mathrm{L}$ zinc acetate $\left[\mathrm{Zn}\left(\mathrm{CH}_{3} \mathrm{CO}_{2}\right)_{2}\right]$ dissolved in ethanol at $90^{\circ} \mathrm{C}$ for $15 \mathrm{~min}$. The seed solution was then spin-coated onto $p$-type GaN templates. Then, the seed-coated $p$-type GaN substrates were thermally annealed at $300^{\circ} \mathrm{C}$ for 5 min to remove the residual solvent [5]. The mixture of the powdered high purity zinc oxide, metallic zinc and graphite in the proportion of 1:1:1 was taken as an initial material for vaporization. This material and $p$-GaN templates were placed into a quartz tube. The mixture of the 
powders was placed in a sealed end of the tube whereas the substrates - near the open end. The quartz tube was placed into a horizontal oven. The powder mixture was heated to the temperature of about $1050^{\circ} \mathrm{C}$ and the substrates were located in the zone with the temperatures of $700-750^{\circ} \mathrm{C}$. These temperature distributions were maintained for $1 \mathrm{~h}$. Afterwards the oven was shut off and cooled spontaneously to room temperature. This yielded a deposited white layer of zinc oxide on the substrates. Since the $p$-GaN substrates were placed with a partial overlap, the $\mathrm{ZnO}$ nanostructure did not grow on the entire substrate surface.

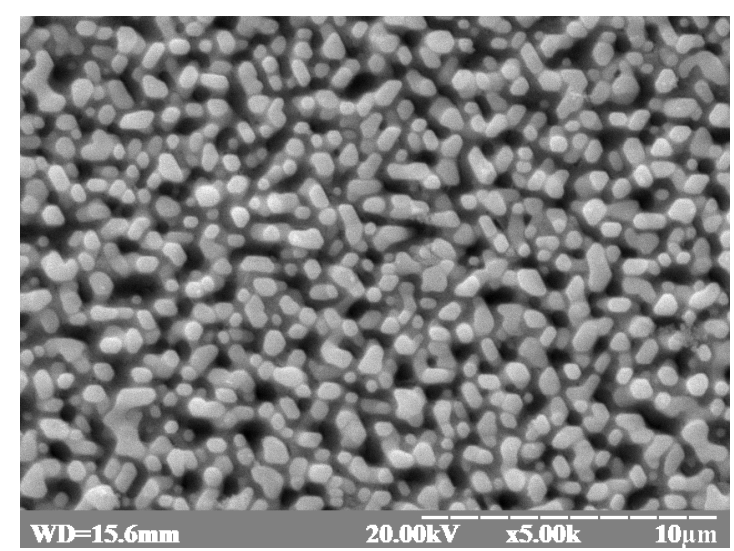

Fig. 1. Microphotographs of $\mathrm{ZnO}$ nanostructures grown using the method of gas-transport reactions and coated with a photoresist

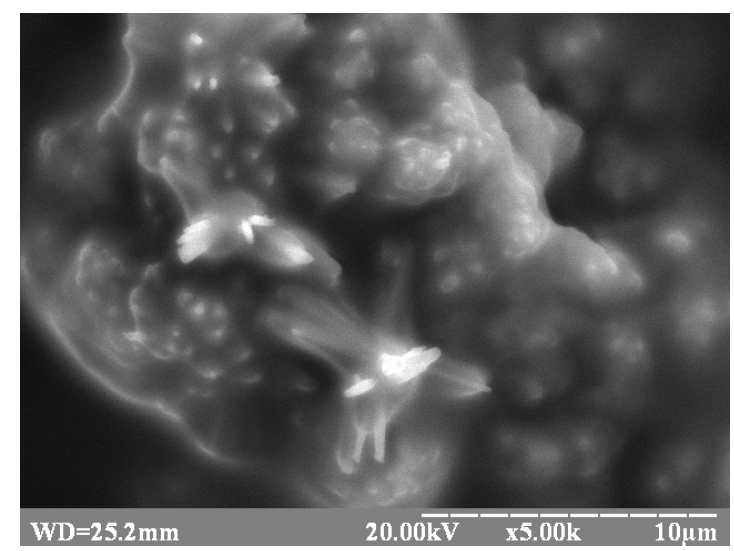

Fig. 2. Microphotographs of $\mathrm{ZnO}$ nanorods grown using the hydrothermal method and coated with a photoresist

Figure 2 shows the $\mathrm{ZnO}$ nanorods grown using the hydrothermal method [6, 7]. For a seed-supported growth of $\mathrm{ZnO}$ nanorods, the nanocrystalline $\mathrm{ZnO}$ seed particles were also prepared on the $p$-GaN templates [5]. At the next stage, the $p$-GaN substrate with $\mathrm{ZnO}$ seeds were immersed in the same main growth solution consisting of $0.05 \mathrm{~mol} / \mathrm{L}$ zinc nitrate hexahydrate $\left(\mathrm{Zn}\left(\mathrm{NO}_{3}\right)_{2} \cdot 6 \mathrm{H}_{2} \mathrm{O}\right)$, $0.025 \mathrm{~mol} / \mathrm{L}$ hexamethylenetetramine $\left(\mathrm{C}_{6} \mathrm{H}_{12} \mathrm{~N}_{4}\right)$ and distilled water. $\mathrm{ZnO}$ nanorods were grown at $90^{\circ} \mathrm{C}$ for $90 \mathrm{~min}$.
The contact with the $p$-GaN was formed using thermally evaporated $\mathrm{Ni}(30 \mathrm{~nm})$ followed by $\mathrm{Au}$ $(35 \mathrm{~nm})$ [3]. The quartz-crystal microbalance was used as a thin-film deposition monitor [8]. The $\mathrm{Ni} / \mathrm{Au}$ contacts were evaporated through the shadow masks in a circular area $\sim 2 \mathrm{~mm}$ in diameter. To produce LEDs, the array of $\mathrm{ZnO}$ nanorods were partially covered with spin coating with an insulator layer of photoresist. This was followed by deposition of $\mathrm{Au} / \mathrm{Ti}$ thin films as the top electrode using the magnetron sputtering method [4]. The $\mathrm{Ti} / \mathrm{Au}$ contacts were evaporated through the shadow masks in a circular area $\sim 2 \mathrm{~mm}$ in diameter. A liquid photo-positive resist based on o-naphto-chinon-diazide and novolack (a type of phenolformaldehyde resin) "Positive 20" KONTAKT CHEMIE was used as the photoresist-insulator [2]. The schematic image of the LEDs is shown in Fig. 3.

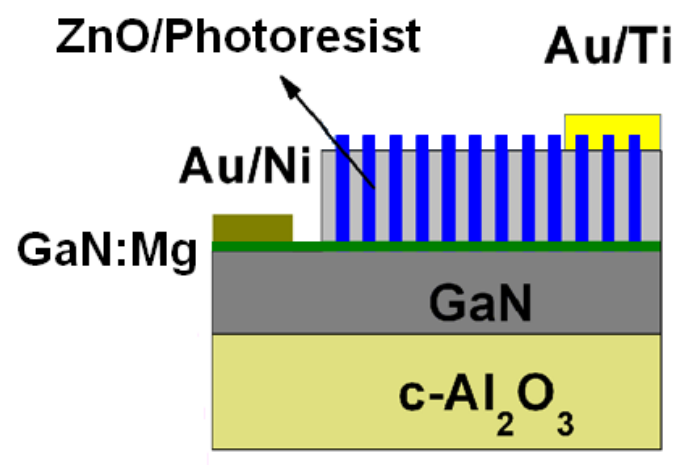

Fig. 3. Schematic image of the LED devices based on $n$ - $\mathrm{ZnO}$ nanorods grown using various methods on $p$-GaN films

The morphology of the samples was examined using REMMA-102-02 Scanning Electron MicroscopeAnalyzer (JCS SELMI, Sumy, Ukraine).

The X-ray diffraction (XRD) measurements were carried out at room temperature using STOE STADI $\mathrm{P}$ diffractometer (STOE \& Cie GmbH, Darmstadt, Germany) with a linear position sensitive detector in the transmission Bragg-Brentano geometry $\left(\mathrm{Cu} K_{\alpha 1}\right.$ radiation at $\lambda=1.540598 \AA$, Ge (111) monochromator, detector scanning step is $0.480^{\circ}(2 \Theta)$, accumulation time is $320 \mathrm{~s}$, $2 \Theta$ angle resolution is $0.015^{\circ}$ ).

The measurements of the current-voltage $(I-V)$ characteristics were carried out using Keithley Model 2401 Low Voltage Source Meter (Keithley Instruments Inc., Ohio, USA) multimeter.

The room-temperature photoluminescence $(\mathrm{PL})$ and EL spectra were measured using a portable fiber optic spectrometer AvaSpec-ULS2048L-USB2-UA-RS (AvantesBV, Apeldoorn, Netherlands) with an input slit of $200 \mu \mathrm{m}$, a diffraction grating of 300 lines $/ \mathrm{mm}$ and a resolution of $9 \mathrm{~nm}$. The accumulation time was $100 \mathrm{msec}$. The detection of light in a spectrometer is carried out by a 2048 pixel CCD detector. Special software for automated computer control of the spectrometer and spectra processing was used. The samples were excited by FQSS266-Q2 Nd:YAG laser (266 nm) for PL. 


\section{RESULT AND DISCUSSION}

The morphology of the $\mathrm{ZnO}$ nanorods grown using two different methods is shown in Figs. 1 and 2. $\mathrm{ZnO}$ nanorods obtained using the method of gastransport reactions were found to possess the diameter ranging from $0.2 \mu \mathrm{m}$ up to $0.5 \mu \mathrm{m}$. They can also form agglomerates of rods with a cross section of not more than $1.5^{-2} \mu \mathrm{m}$. $\mathrm{ZnO}$ nanorods grown using the hydrothermal method are characterized by the length of about 3-4 $\mu \mathrm{m}$ and an average diameter of about 200$500 \mathrm{~nm}$.

The XRD pattern of the $\mathrm{ZnO}$ nanorods is illustrated in Fig. 4. The obtained peaks correspond to the hexagonal wurtzite pure phase of the $\mathrm{ZnO}$ with the lattice parameters $a=b=3.2476 \pm 0.0014 \AA, c=5.2037 \pm$ $0.0029 \AA$ for $\mathrm{ZnO}$ nanorods obtained using the method of gas-transport reactions and $a=b=3.2451 \pm 0.0015 \AA$, $c=5.1963 \pm 0.0035 \AA$ for the $\mathrm{ZnO}$ nanorods grown using the hydrothermal method. This result indicates that no other phases of $\mathrm{ZnO}$ or impurities are observed [9].

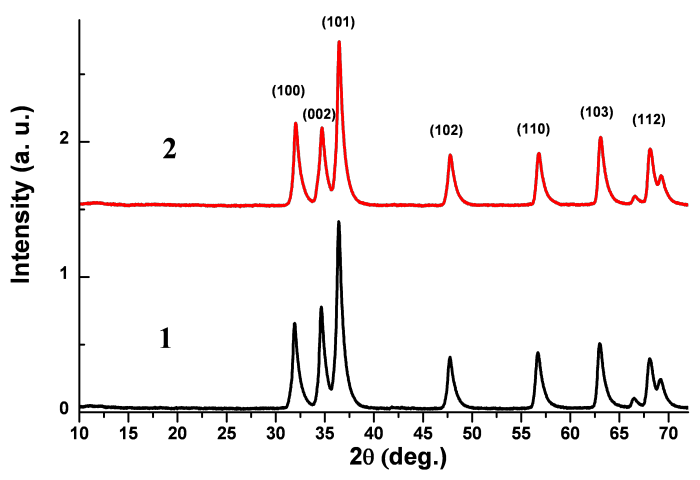

Fig. 4. XRD spectra of $\mathrm{ZnO}$ nanorods grown using: 1 the hydrothermal method; 2 - the method of gas-transport reactions

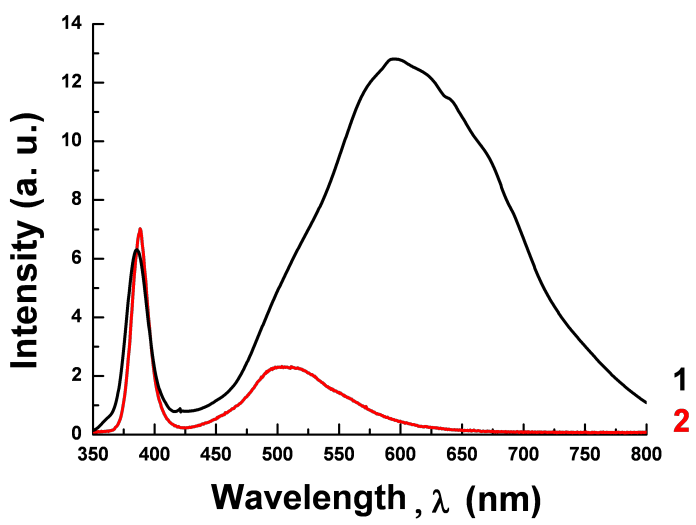

Fig. 5. The room temperature PL spectra: $1-\mathrm{ZnO}$ nanorods grown using the hydrothermal method; $2-\mathrm{ZnO}$ nanorods grown using the method of gas-transport reactions

The room-temperature $\mathrm{PL}$ spectra of the $\mathrm{ZnO}$ nanorods (Fig. 5) grown using different methods consist of the two bands in the UV and visible regions. The band at $388 \mathrm{~nm}$ is typical of $\mathrm{ZnO}$ and arises due to the recombi- nation of the free excitons, bound excitons and transitions in the donor-acceptor pairs [6]. The wide band in the range from approximately $450 \mathrm{~nm}$ to $750 \mathrm{~nm}$ is caused by defects, first of all, by uncontrolled impurities and stoichiometry defects [6].

For the $\mathrm{ZnO}$ nanorods grown using the hydrothermal method, the broad luminescence peak near $600 \mathrm{~nm}$ according to $[6,7]$ originates from the hydroxyl groups attached to the $\mathrm{ZnO}$ nanorods.

In our previous paper, the results of PL studies of $p$ type GaN templates purchased from UNIPRESS were presented [3]. The PL spectrum for Mg-doped GaN consisted of the narrow neutral acceptor bound exciton (ABE) band at $3.43 \mathrm{eV}$ and the broad donor-acceptor pair (DAP) band at $3.27 \mathrm{eV}$.

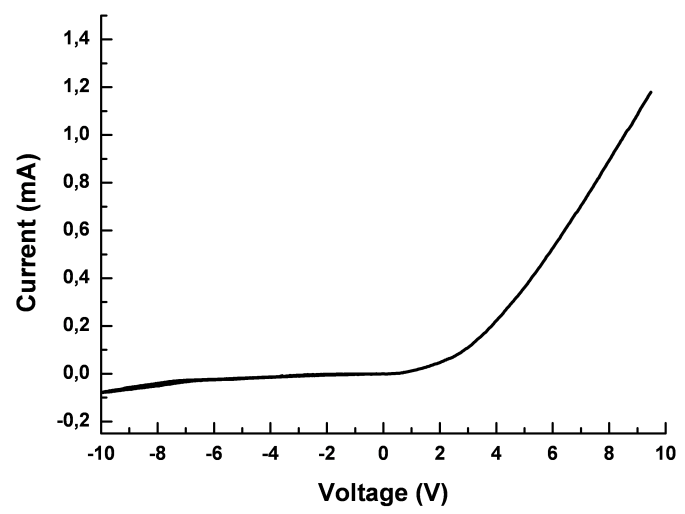

a)

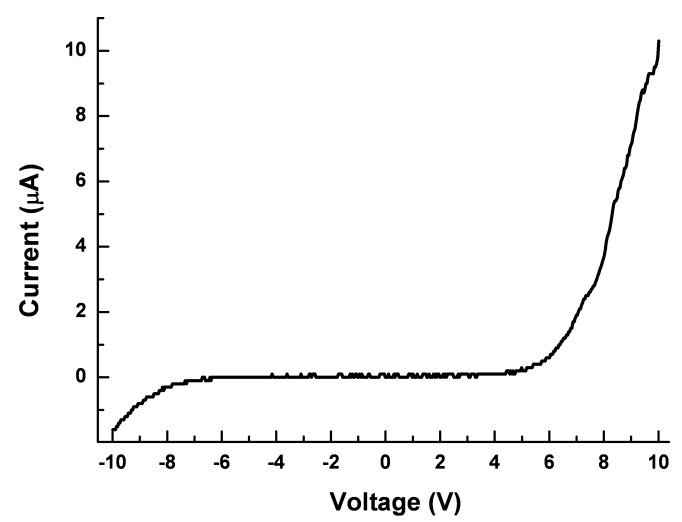

b)

Fig. 6. $I-V$ characteristics of the LEDs created on the basis of $\mathrm{ZnO}$ nanorods grown using the method of gas-transport reactions (a) and $\mathrm{ZnO}$ nanorods grown using hydrothermal $\operatorname{method}(\mathrm{b})$

The $I-V$ characteristics of the LEDs created on the basis of $\mathrm{ZnO}$ nanorods grown using the two different methods are depicted in Fig. 6. The $I-V$ curves clearly show a nonlinear increase in the current under the forward bias, which indicates reasonable $p-n$ junction characteristics and possibility of light emission. The diode turn-on voltage is defined as the inflection voltage that is determined by extrapolating the fitting line corresponding to the linear region of the forward $I-V$ 
characteristics to the abscissa axis. The turn-on voltages of the heterojunctions of $\mathrm{ZnO} / \mathrm{GaN}$ in the cases of the $\mathrm{ZnO}$ nanorods grown using the gas-transport reaction and the hydrothermal methods were equal to $3.2 \mathrm{~V}$ and $6.5 \mathrm{~V}$, respectively. The diode-ideality factors $(\eta)$ were estimated from the slopes of the $\ln (I)$ versus $V$ plots in the range from 2 to $7 \mathrm{~V}$, using the equation:

$$
\eta=e / k_{\mathrm{B}} T[\delta(\ln I) / \delta V]^{-1}
$$

where $k_{\mathrm{B}}$ is the Boltzmann constant and $T$ is the operating temperature.

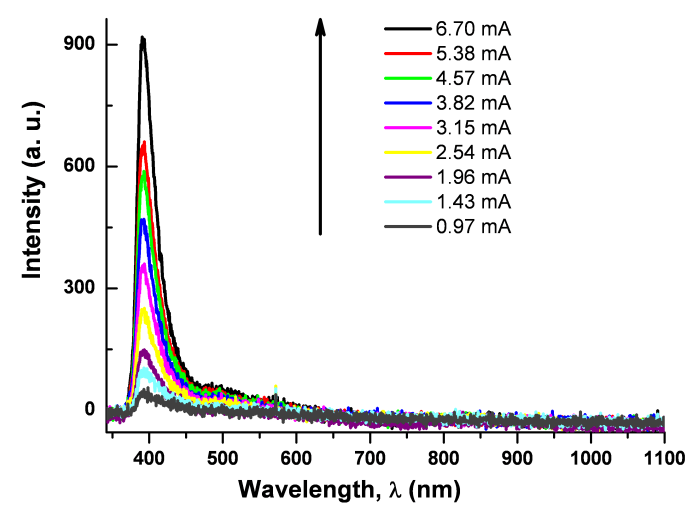

a)

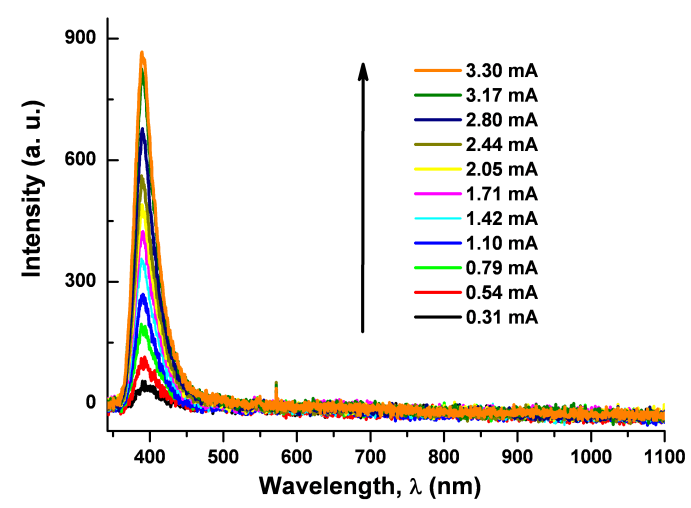

b)

Fig. 7. Room temperature EL spectra of the LEDs under different injected currents at forward bias: LED on the basis of $\mathrm{ZnO}$ nanorods grown by the method of gas-transport reactions (a) and LED on the basis of $\mathrm{ZnO}$ nanorods grown by the hydrothermal method (b)

In our case the diode-ideality factors were found to be around 45 and 36 for the samples with $\mathrm{ZnO}$ nanorods grown using the gas-transport reaction and hydro-thermal methods, respectively. These results are in agreement with the data of the current-voltage behavior of $n-\mathrm{ZnO} / p-\mathrm{GaN}$ heterostructures presented in [10, 11]. Indeed, as it was reported by Le et al. [10], the value of the ideality factor was $\eta=15$, whereas in [11] $-\eta \sim 48$. The large values of the ideality factor indicate a high density of trap states [12]. The considerable deviation of $\eta$ from the ideal case $(\eta=1$ for the thermionic emission model) may be also linked to the quality of the contacts to the $p-n$ junction $[10,13]$.

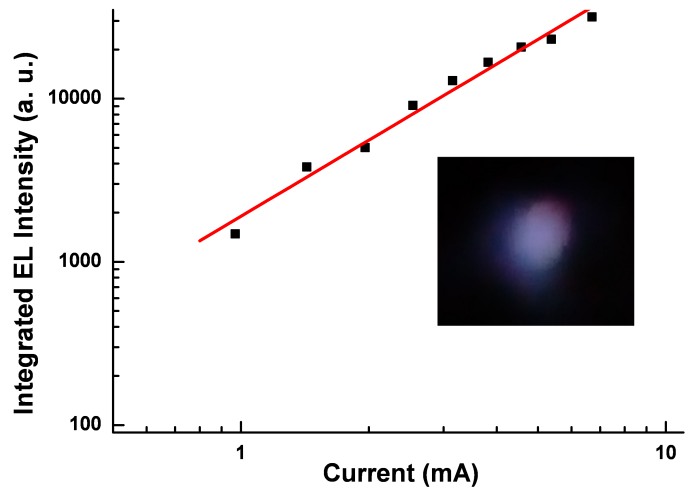

a)

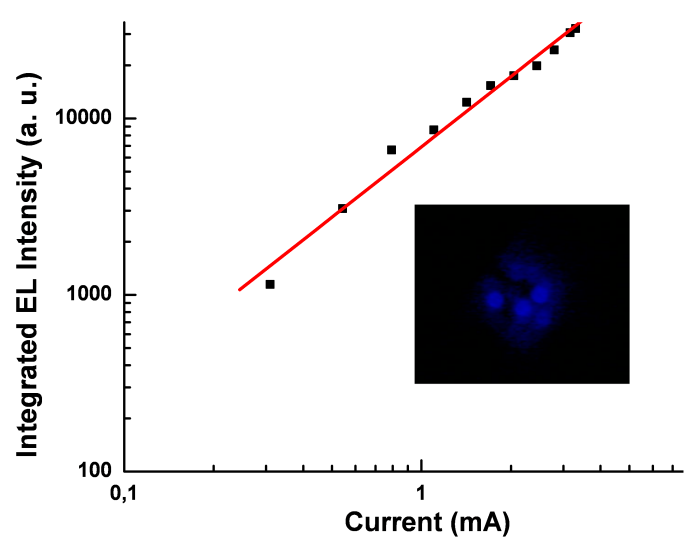

b)

Fig. 8. Integrated EL intensity of the investigated $n$ - $\mathrm{ZnO}$ nanorods $/ p$-GaN diode structures as a function of the injection current (the solid lines represent the fitting results based on the power law $L=C I^{n}$ ): LED obtained on the basis of $\mathrm{ZnO}$ nanorods grown using the method of gas-transport reactions (insert - photograph of light emission at the forward current of $6.7 \mathrm{~mA}$ ) (a), LED obtained on the basis of $\mathrm{ZnO}$ nanorods grown using the hydrothermal method (insert - photograph of light emission at the forward current of $3.3 \mathrm{~mA})(\mathrm{b})$

EL spectra of $n-\mathrm{ZnO} / p$-GaN LEDs created on the basis of $\mathrm{ZnO}$ nanorods grown using the two different methods are shown in Fig. 7. The EL spectra of both LEDs containe a single band in the UV region with a maximum at $390 \mathrm{~nm}$. With the increase in injected currents the emission peak was significantly enhanced.

It should be noted that there is some difference between the PL and EL processes. The PL process depends on the recombination of nonequilibrium carriers in the surface layer, whereas the EL process is determined via the carrier recombination within the space charge region of the heterojunction. On the other hand, the junction heating effect under a constant injection current will cause band bending consequently leading to the red shift in the EL peak.

In order to clarify the mechanism of the variation in the EL intensity of $n$ - $\mathrm{ZnO} / p$-GaN LEDs, the integrated 
intensity of the EL peak as a function of the injection current in a log-log scale is plotted in Fig. 8. The results can be fitted with the power law $L=c I^{n}$, where $\mathrm{n}$ accounts for the influence of non-radiative defects in the characteristics of light emission [4, 14]. A linear increase in $L$ with $I$, i.e., $n=1$ can be expected when radiative recombination dominates, while non-radiative recombination becomes dominant when $L$ shows a superlinear dependence on $I$, i.e., when $n>1$.

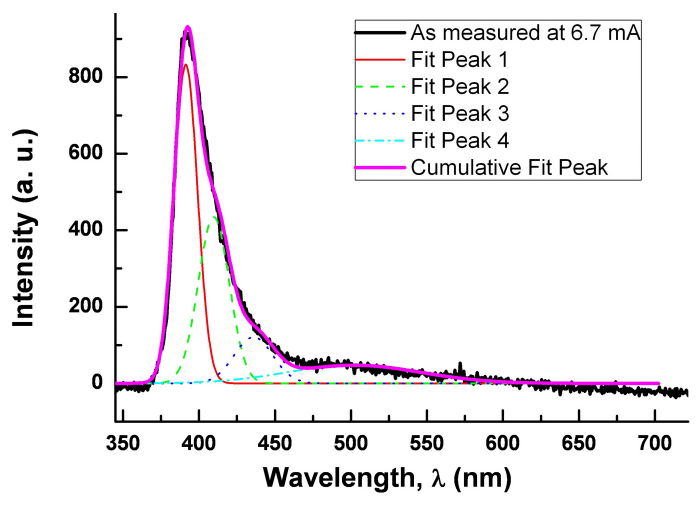

a)

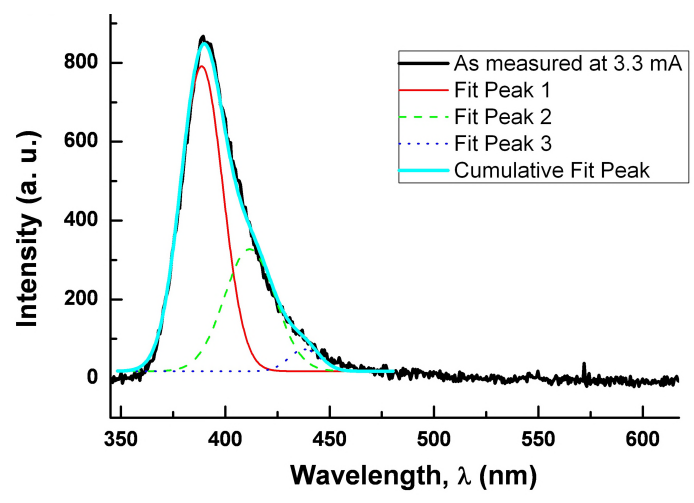

b)

Fig. 9. Gaussian fits of the EL spectra of LEDs created on the basis of: $\mathrm{ZnO}$ nanorods grown by the method of gas-transport reactions (a), $\mathrm{ZnO}$ nanorods grown by hydrothermal method (b)

Our result shows dependence with $n \simeq 0.99$ for both $n$ $\mathrm{ZnO} / p$-GaN LEDs. This value indicates a low impact of non-radiative recombination centers in the space-charge region.
In order to understand the origin of the light emission, the EL bands in the spectra of LEDs based on $\mathrm{ZnO}$ nanorods grown using the method of the gastransport reaction and the hydrothermal method, were decomposed into four and three Gaussian parts, respectively, as is shown in Fig. 9. The emission peaks at 389-391, 410-412 and 436-438 nm correspond to the near-band-edge (NBE) recombination of $\mathrm{ZnO}$ [15-17], interface carriers recombination of $\mathrm{ZnO} / \mathrm{GaN}[1,18]$ and to the electrons' transition from the GaN conduction band to $\mathrm{Mg}^{2+}$ doping level, respectively [1, 18]. On the basis of the literature data $[2,19,20]$ and our experimental results, the luminescence band with a maximum at $502 \mathrm{~nm}$ would be related to the emission from the defect levels in $\mathrm{ZnO}$.

\section{CONCLUSION}

In summary, one can conclude that $n$ - $\mathrm{ZnO}$ nanorods / $p$-GaN film heterojunction LEDs structures have been created on the basis of $\mathrm{ZnO}$ nanorods prepared using the gas-transport reactions and hydrothermal methods. LEDs of the both types showed UV emission at different values of the forward injection currents.

The bands in EL spectra of the LEDs with $\mathrm{ZnO}$ nano-rods grown using the method of the gas-transport reaction and the hydrothermal method were decomposed into four and three Gaussian parts, respectively. On the basis of the data of XRD, electrical and optical studies, one can conclude that the emission peaks at 389-391, 410-412, 436-438 and $502 \mathrm{~nm}$ correspond to the NBE recombination of $\mathrm{ZnO}$, interface carriers' recombination of $\mathrm{ZnO} / \mathrm{GaN}$, the electrons' transition from the $\mathrm{GaN}$ conduction band to $\mathrm{Mg}^{2+}$ doping level, and to the emission from the defect levels in $\mathrm{ZnO}$, respectively. However, a LED based on $\mathrm{ZnO}$ nanorods synthesized using the hydrothermal method emitted more pure UV light.

The obtained results would be fruitful for designing highly-efficient, low cost nanoscale heterojunction UV LEDs with optimized parameters.

\section{AKNOWLEDGEMENTS}

This work was supported by the Ministry of Education and Science of Ukraine.
[1] D. You et al., Sci. Bull. 63, 38 (2018); https://doi.or g/10.1016/j.scib.2017.12.006.

[2] V. Kapustianyk et al., Phys. Stat. Solidi (c) 11, 1501 (2014); https://doi.org/10.1002/pssc.201300671.

[3] B. Turkoet al., Opt. Quant. Electron. 51, 135 (2019); https://doi.org/10.1007/s11082-019-1853-5.
[4] J. J. Dong et al., Appl. Phys. Lett. 100, 171109 (2012); https://doi.org/10.1063/1.4706259.

[5] W. M. Choi et al., Nano Res. 4, 440 (2011); https://do i.org/10.1007/s12274-011-0100-6.

[6] V. Kapustianyk et al., Opt. Mater. 56, 71 (2016); https: //doi.org/10.1016/j.optmat.2016.01.057. 
[7] L. Toporovska et al., Opt. Quant. Electron. 49, 408 (2017); https://doi.org/10.1007/s11082-017-12546.

[8] A. Wajid, Sens. Actuators A 63, 41 (1997); https://do i.org/10.1016/S0924-4247 (97) 80427-X.

[9] R. E. Adam, H. Alnoor, S. Elhag, O. Nur, M. Willander, in Proc. SPIE. Oxide-based Materials and Devices VIII 10105, 101050X (2017); https://doi.org/10.1117/12 .2254872 .

[10] H. Q. Le, S. J. Chua, E. Fitzgerald, K. P. Loh, Adv. Mater. Micro Nano Syst. 1, 1 (2007).

[11] Y.-J. Lee et al., APL Mater. 2, 056101 (2014); https: //doi.org/10.1063/1.4874455.

[12] A. Gokarna, N. R. Pavaskar, S. D. Sathaye, V. Ganesan, S. V. Bhoraskar, J. Appl. Phys. 92, 2118 (2002); https: //doi.org/10.1063/1.1483381.

[13] K. Kim, T. Moon, J. Kim, S. Kim, Nanotechnology 22, 245203 (2011); https://doi.org/10.1088/0957-4484/
$22 / 24 / 245203$

[14] J. D. Ye et al., Appl. Phys. Lett. 88, 182112 (2006); https://doi.org/10.1063/1.2201895.

[15] J. C. Sun et al., Appl. Phys. Lett. 90, 121128 (2007); https://doi.org/10.1063/1.2716206.

[16] S. Chu, J. H. Lim, L. J. Mandalapu, Z. Yang, L. Li, J. L. Liu, Appl. Phys. Lett. 92, 152103 (2008); https: //doi.org/10.1063/1.2908968.

[17] K. Nakahara et al., Appl. Phys. Lett. 97, 013501 (2010); https://doi.org/10.1063/1.3459139.

[18] G. Y. Zhu et al., Appl. Phys. Lett. 101, 041110 (2012); https://doi.org/10.1063/1.4739002.

[19] S. P. Chang, R. W. Chuang, S. J. Chang, Y. Z. Chiou, C. Y. Lu, Thin Solid Films 517, 5054 (2009); https: //doi.org/10.1016/j.tsf.2009.03.059.

[20] N. H. Alvi, K. Hasan, O. Nur, M. Willander, Nanoscale Res. Lett. 6, 130 (2011); https://doi.org/10.1186/15 $56-276 \mathrm{X}-6-130$.

\title{
УЛЬТРАФІОЛЕТОВА ЕЛЕКТРОЛЮМІНЕСЦЕНЦІЯ СВІТЛОДІОДНИХ ПРИСТРОЇВ НА ОСНОВІ НАНОСТРИЖНІВ $n$-ZnO, ВИРОЩЕНИХ ЗА РІЗНИМИ МЕТОДАМИ, ТА ПЛІВОК $p$-GaN
}

\author{
Б. І. Турко ${ }^{1 *}$, А. С. Ніколенко ${ }^{2}$, Б. С. Садовий ${ }^{3}$, Л. Р. Топоровська ${ }^{1}$, М. С. Рудко ${ }^{1}$ В. Б. Капустяник ${ }^{1}$, \\ В. В. Стрельчук ${ }^{2}$, Р. Я. Серкіз ${ }^{1}$, Ю. О. Кулик ${ }^{1}$ \\ ${ }^{1}$ Львівсъкий начіональний університет імені Івана Франка, \\ вул. Драгоманова, 50, Лъвів, 79005, Украӥна, \\ ${ }^{2}$ Інститут фізики напівпровідників ім. В. Є. Лашкаръова НАН Украӥни, \\ просп. Науки, 41, 03028, Київ, Украӥна, \\ ${ }^{2}$ Інститут фізики високого тиску, \\ вул. Соколовсъка, 29/37, 01-142, Варшава, Польща
}

Створено світловипромінювальні діодні структури (світлодіоди) на основі гетеропереходу плівка $p$ - $\mathrm{GaN} / n$ - ZnO квазішар із нанострижнів. ZnO наноструктури вирощено двома різними методами на поверхні підкладок $\mathrm{GaN}$ з р-типом провідності. Морфологію поверхні експериментальних зразків досліджено за допомогою растрового електронного мікроскопа. Нанострижні ZnO, отримані методом газотранспортних реакцій, мали діаметр від 0.2 мкм до 0.5 мкм, і деякі. 3 них утворювали агломерати стрижнів із поперечним діаметром не більшим за 1.5-2 мкм. Нанострижні ZnO, вирощені гідротермічним методом, мали довжину приблизно 3-4 мкм і середній діаметр - приблизно 200-500 нм. Спектри фотолюмінесценції виміряні за кімнатної температури нанострижнів ZnO, вирощених двома різними методами, містили дві смуги в ультрафіолетовому та видимому діапазонах хвиль світла. Смуга з максимумом за 388 нм є типовою для ZnO і може виникати внаслідок рекомбінації вільних екситонів, зв'язаних екситонів та переходів у донорно-акцепторних парах. Широка смуга в межах приблизно від 450 нм до 750 нм пов'язана з дефектами, насамперед із неконтрольованими домішками та дефектами стехіометрії. Напруги ввімкнення гетеропереходів $\mathrm{ZnO} / \mathrm{GaN}$ у світлодіодах із нанострижнів $\mathrm{ZnO}$, вирощених, дорівнювали $6.5 \mathrm{~B}$ і $3.2 \mathrm{~B}$ відповідно. Отримані значення факторів ідеальності діода приблизно мали 36 і 45 для зразків з нанострижнями ZnO, вирощеними гідротермічним та газотранспортних реакцій методами відповідно. Великі значення факторів ідеальності вказують на високу щільність станів пасток і також можуть бути пов'язаними з якістю контактів до $p-n$ переходів. Спектри електролюмінесценції світлодіодів із нанострижнів $\mathrm{ZnO}$, вирощених методом газотранспортних реакцій та гідротермічним методом, апроксимовано, відповідно, чотирма та трьома гаусіанами. На основі даних дифракції Х-променів, електричних та оптичних досліджень піки електролюмінесценції за 389-391, 410-412, 436-438 та 502 нм пов'язано з прикрайовою емісією в ZnO, інтерфейсною рекомбінацією носіїв у ZnO/GaN-переході, електронними переходами зі зони провідності GaN на рівень легуючої домішки $\mathrm{Mg}^{2+}$ та з емісією з дефектного рівня в $\mathrm{ZnO}$ відповідно. Світлодіод на основі нанострижнів $\mathrm{ZnO}$, вирощених гідротермічним методом, випромінював чистіше ультрафіолетове світло.

Ключові слова: оксид цинку, нітрид галію, нанострижні, гетероперехід, електролюмінесценція. 